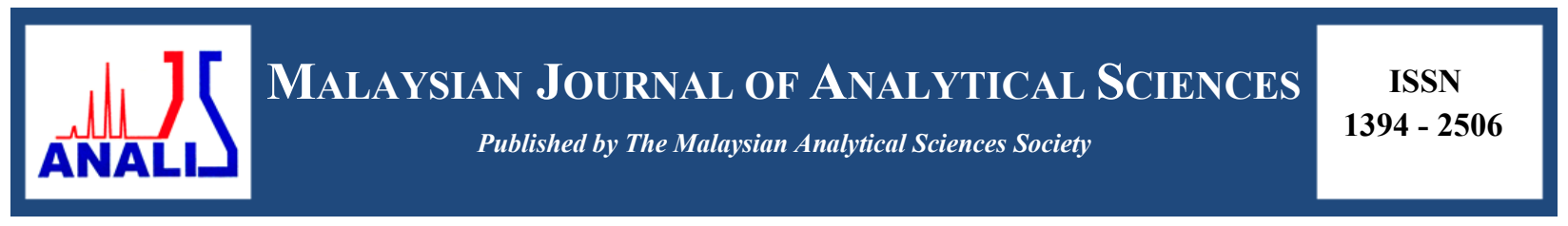

\title{
SYNTHESIS AND CHARACTERIZATION OF MESOPOROUS POLYMER- SILICA HYBRID MONOLITH USING CONVENTIONAL SOL-GEL METHOD FOR ENZYME SUPPORT
}

\author{
(Sintesis dan Pencirian Monolit Hibrid Polimer-Silika Berliang-Meso Menggunakan Kaedah \\ Konvensional Sol-Gel Untuk Bertindak Sebagai Sokongan Enzim)
}

\author{
Noor Hidayah Idrohani ${ }^{1}$, Samuel M. Mugo ${ }^{2}$, Sabiqah Tuan Anuar ${ }^{1}$ * \\ ${ }^{1}$ School of Marine and Environmental Sciences, \\ Universiti Malaysia Terengganu, 21030 Kuala Nerus, Terengganu, Malaysia \\ ${ }^{2}$ Department of Physical Sciences, \\ Mac Ewan University, Edmonton, Alberta, T5J 4S2, Canada \\ *Corresponding author: sabiqahanuar@umt.edu.my
}

Received: 26 August 2017; Accepted: 2 January 2018

\begin{abstract}
This research involved developing a novel solid support for an enzyme attachment, focusing on synthesizing a polymer-silica hybrid monolith via in-situ sol-gel polymerization method. The fabrication of a very large surface area of the monolith was done using a cold mixture of poly(ethylene-glycol) (PEG) with tetraethyl-orthosilicate (TEOS) and acetic acid with different ratios of PEG amount and molecular weights, namely PEG-0.1, PEG-0.2, and PEG-0.3. The experiments were conducted at a very low temperature of $0{ }^{\circ} \mathrm{C}$, followed by overnight gelification and aging. The sol then underwent calcination at $200{ }^{\circ} \mathrm{C}$ forming a hybrid monolith. The characterizations of hybrid monoliths were performed by Attenuated-Total Reflection-Fourier Transformed Infrared Spectroscopy (ATR-FTIR), Scanning Electron Microscope (SEM), and Surface Area and Porosity Analyzer using both Brunauer-Emmett-Teller (BET) and Barrett-Joyner-Halenda (BJH) methods to describe the developed monoliths. FTIR shows the presence of Si-O-Si stretching associated with the monolith network due to the polymerization process together with the presence of silanol functional group (Si-OH) that can be exploited further for covalent attachment with the enzyme. Results also showed that the optimum ratios for the hybrid polymer-silica synthesis were PEG-0.1with $10,000 \mathrm{M}_{\mathrm{n}}$ surface area of mesoporous network recorded for $494.121 \mathrm{~m}^{2} / \mathrm{g}$ and pore volume of $0.265 \mathrm{~cm}^{3} / \mathrm{g}$. These findings showed that the synthesized hybrid monolith on fused silica capillary will provide a vast surface area with desirable functional groups; thus, very promising for lipase immobilization support that can be used in future small-scale lipid transformation.
\end{abstract}

Keywords: hybrid monolith, fused silica capillary, sol-gel polymerization, enzyme support, mesoporous monolith

\section{Abstrak}

Penyelidikan ini melibatkan penghasilan satu sokongan baru untuk tautan enzim yang mana berfokuskan kepada sintesis monolit hibrid polimer-silika melalui kaedah pempolimeran sol-gel secara in-situ. Pemfabrikatan monolit yang mempunyai luas permukaan yang sangat besar telah dilakukan menggunakan campuran sejuk daripada poli(etilina-glikol)(PEG) dengan tetraetilortosilikat (TEOS) dan asid asetik pada nisbah bagi jumlah dan berat molekular PEG yang berbeza, dan dinamakan PEG-0.1, PEG-0.2 dan PEG-0.3. Eksperimen telah dijalankan dalam suhu yang sangat rendah pada $0^{\circ} \mathrm{C}$ diikuti dengan pengegelan dan penuaan untuk semalaman. Sol tersebut kemudiannya melalui proses kalsinasi pada suhu $200{ }^{\circ} \mathrm{C}$ lalu membentuk hibrid monolit. Hibrid monolit yang dihasilkan telah dicirikan melalui inframerah transformasi Fourier (FTIR), mikroskop pengimbas elektron (SEM) dan penganalisa rongga dan luas permukaan menggunakan kaedah Brunauer-Emmett-Teller (BET) dan Barrett-JoynerHalenda (BJH) untuk menggambarkan monolit yang telah terbentuk. Keputusan dari FTIR menunjukkan kehadiran regangan SiO-Si daripada jaringan monolit disebabkan proses pempolimeran, bersama-sama dengan kehadiran kumpulan berfungsi silanol 


\section{Noor Hidayah et al: SYNTHESIS AND CHARACTERIZATION OF MESOPOROUS POLYMER-SILICA HYBRID MONOLITH USING CONVENTIONAL SOL-GEL METHOD FOR ENZYME SUPPORT}

(Si-OH) yang boleh dieksplotasi untuk digunakan di dalam tautan kovalen dengan enzim. Didapati bahawa nisbah optima bagi sintesis polimer-silika hibrid adalah PEG-0.1 dengan berat molekul $10,000 \mathrm{M}_{\mathrm{n}}$, yang mempunyai luas permukaan bagi jaringan liang-meso sebanyak $494.121 \mathrm{~m}^{2} / \mathrm{g}$ dan isipadu liang $0.265 \mathrm{~cm}^{3} / \mathrm{g}$. Keputusan tersebut menunjukkan hibrid monolit yang disintesis di dalam kapilari silika kosong boleh menghasilkan luas permukaan yang sangat besar, dan berpotensi sebagai sokongan untuk pemegunan lipase bagi transformasi lipid berskala kecil di masa hadapan.

Kata kunci: campuran monolit, kapilari silika kosong, pempolimeran sol-gel, sokongan enzim, monolit berliang-meso

\section{Introduction}

To date, there are great interests in monolith fabrications for various analytical applications, especially in chromatography and catalysis. The wide range of monoliths has been developed with a variety and versatile class of materials as they can be easily prepared with varying porosity, pore size, and various chemical functionalities during the polymerization process [1]. Generally, monolith can be defined as a column or capillary that consists of a single large block of stone, particularly derived from the Greek word monolithos with monos meaning "single" and lithos, "stone", respectively [2]. A monolith can be described as a continuously interconnected skeleton with large throughpores [3]. Meanwhile, according to IUPAC, a monolith is a shaped and intractable network with a homogenous fabricated microstructure in which it does not show any structural components discernible by optical microscopy [4, 5]. Fundamentally, the monolith structures comprise of a honeycomb-like structure accompanied by many thin, vertical, and parallel channels of layers of a continuous uniform porous support material [6]. Monoliths are broadly categorized but the organic- and inorganic-based monoliths are widely used for their classification purpose. Most of the monoliths are made by a combination of several monomers or can simply be one monomer being transformed with certain modifications [2]. For an organic monolith, the pre-polymerization mixture of monolith can contain monomers or porogen, crosslinkers, initiators, and porogenic solvents in a mold before polymerization takes place $[7]$.

Common materials being utilized in the polymeric monolith include styrene and methacrylate together with other acrylamide-based monomers where the polymerizable vinyl groups can be prepared in-situ within the capillary or column by radical polymerization using heat or UV reaction $[2,7,8]$. To date, a vast variety of organic polymer based-monoliths have been prepared, for instance, poly(glycidyl methacrylate-co-ethylene dimethacrylate) [9, 10], poly(N-acryloyltris (hydroxymethyl)aminomethane-co-pentaerythritol triacrylate) (NAHAM- co-PETA) [11], poly(butyl methacrylate-co-ethylene glycol dimethacrylate) [12], 3-(trimethoxysilyl)propylmethacrylate modified graphene oxide [13], and palladium-Schiff-base functionalized methyl methacrylate-glycidyl methacrylate (MMAGMA) [14]. The monoliths prepared with this technique can still maintain their stability and have even gone through very high $\mathrm{pH}$ conditions. However, in the major scenarios, shrinkage and swelling cannot be avoided, especially when they were exposed to other mobile phases such as organic solvents, hence resulting in the low mechanical stability [15] that limits their application.

Thus, the modification of this type of monolith with an inorganic material such as silica is needed in order to increase their application. Previously, silica-based (inorganic) monoliths were generally prepared by the process of sol-gel and their surface eventually underwent silanization modifications [16]. On the contrary to the polymer monoliths that are easily swelled and undergone decomposition under solvent or temperature changes, silica monoliths are sufficiently great, even under extreme conditions [16, 17]. However, the drawbacks that cannot be fully neglected in preparing silica monolith are the shrinkage and cracking of the monolith itself [2, 16, 18, 19]. Therefore, the sol-gel hybrid materials have attracted huge attentions and proven to be promising since they have the merits from both earlier types of monolith, especially their outstanding mechanical strength and stability, as well as excellent $\mathrm{pH}$ stability $[2,20]$. Nevertheless, the fabrication of polymer-silica hybrid monolith presented herein showed the improvements of this type of support due to the ease of preparation with the higher surface area and minimal shrinkage as the major benefits. Moreover, it was demonstrated in this study that the mesoporous networks of the monolith could be tailored differently with different ratios of monomer or porogen.

\section{Materials and Methods}

Polyethylene glycol (PEG; $\mathrm{M}_{\mathrm{n}}=10,000$ and 20,000), tetraethylorthosilicate (TEOS, 98\%), acetic acid glacial, sodium hydroxide, hydrochloric acid, and methanol were purchased from Fluka/Sigma-Aldrich (Sigma-Aldrich, 
Missouri, USA). The fused-silica capillary of $530-\mu \mathrm{m}$ I.D and $700-\mu \mathrm{m}$ O.D was purchased from Polymicro Technologies (Molex Singapore Pte. Ltd., Singapore). A precise NE-300 infusion syringe pump (New Era Pump System Inc., New York, USA) was used to infuse the substrates through capillaries.

\section{Preparation of polymer-silica hybrid monolith capillary}

The preparation conditions of the monolithic silica-hybrid columns were similar to those reported previously but with some modification $[19,21,22]$. Prior to use, a fused-silica capillary was cut into $15-20 \mathrm{~cm}$ in length and treated with $0.1 \mathrm{~mol} \mathrm{HCl}$ for 2 hours, water for 0.5 hour, $0.1 \mathrm{~mol} \mathrm{NaOH}$ for 2 hours, water for 0.5 hour, and methanol for 0.5 hour, respectively. The resultant capillary was dried by a flow of nitrogen. The polymerization mixture was prepared by mixing $0.45 \mathrm{ml}$ TEOS and $1 \mathrm{ml} 0.01 \mathrm{M}$ acetic acid with either $0.1 \mathrm{~g}$ PEG (PEG-0.1), $0.2 \mathrm{~g}$ PEG (PEG-0.2) or 0.3 g PEG (PEG-0.3). The optimum PEG weight (PEG-0.1) was later evaluated for different molecular weights (PEG-0.1 at $10,000 \mathrm{M}_{\mathrm{n}}$ and $20,000 \mathrm{M}_{\mathrm{n}}$ ). The mixture was then agitated using a vortex mixer to promote the hydrolytic reaction in an ice that was maintained at $0{ }^{\circ} \mathrm{C}$ for 40 minutes. The pretreated fused silica capillary was then filled with the transparent cold sol using a flow infusion pump at a flow rate of $5 \mu \mathrm{l} / \mathrm{min}$ for 1.5 hour. Both ends of the capillary were then sealed with septum before being submerged into the thermostatic bath at $42{ }^{\circ} \mathrm{C}$ for 24 hours. Lastly, calcination was carried out at $200{ }^{\circ} \mathrm{C}$ for 24 hours in a furnace oven, resulting in the decomposition of organic moieties in the capillary. After this, the polymer-silica hybrid monolith was ready for characterizations.

\section{Evaluation of the hybrid monolithic capillary}

Attenuated-Total Reflection (ATR) Fourier Transform Infrared (FTIR) spectroscopy (IR Tracer-100 SHIMADZU, Kyoto, Japan) was used to characterize the surface functional groups of the monolith. Before the characterization, the diamond ATR crystal was solvent washed and dried, then an infrared background was collected. A small amount of monolith sample was prepared and loaded onto the ATR crystal and scanned to acquire the IR spectra. The scan rate was set to 20 spectra per seconds.

The surface morphology of monolith was determined using SEM (JOEL JSM-6360LA, Massachusetts, USA). Samples were prepared by cutting the fused silica capillary to a length of 1-2 $\mathrm{mm}$ and mounted on stainless steel stub. The mounted samples were coated with a thin layer of gold before being placed into a holder. Subsequently, all the samples were transferred into the SEM chamber. SEM was operated at $16 \mathrm{kV}$ with magnifications of 3000 magnification and 5000 magnifications.

The Surface Area and Porosity Analyzer (Micromeritics, Georgia, USA) was used for evaluating the monoliths. Nitrogen adsorption/desorption isotherms were measured by ASAP 2020 Micromeritics surface area analyzer at $196{ }^{\circ} \mathrm{C}$. The specific surface areas of monoliths were assessed according to the standard Brunauer- Emmett-Teller (BET) method. The pore size distributions and total pore volume were also determined from the adsorption branches of isotherms by the Barrett-Joyner-Halenda (BJH) method.

\section{Results and Discussion}

In this paper, the synthesis and characterization of polymer-silica hybrid monolith support prepared in-situ and rapidly in fused silica capillary tubing were demonstrated. The monolith was synthesized using poly(ethyleneglycol) (PEG) as an organic sol-gel precursor and monomer into the sol-gel solution which consisted of tetraethyl orthosilicate (TEOS) and acetic acid (AA). The PEG that also acted as a porogen in the synthesis monomers where the polymerizable vinyl groups from PEG were utilized to make mesopore networks with the TEOS. In this process, the incorporation of the precursor was proven to be vital as it possessed an octadecyl moiety [23]. The effects of adding different types and weights of PEG (PEG with molecular weights of $10,000 \mathrm{M}_{\mathrm{n}}$ and 20,000 $\mathrm{M}_{\mathrm{n}}$ at $0.1 \mathrm{~g}, 0.2$ $\mathrm{g}$, and $0.3 \mathrm{~g}$ ) to a pre-polymerization mixture were studied in order to understand the effect of porogen addition for the purpose of making very porous monolith that can still provide a higher surface area. The introduction of PEG as a porogen material will eventually provide the mesoporous structure of a monolithic network. To evaluate this, ATR-FTIR, SEM, and Surface Area and Porosity Analyzer using BET and BJH methods were all used in the characterization. 


\section{Noor Hidayah et al: SYNTHESIS AND CHARACTERIZATION OF MESOPOROUS POLYMER-SILICA HYBRID MONOLITH USING CONVENTIONAL SOL-GEL METHOD FOR ENZYME SUPPORT}

The surface functional groups presented on the polymer-silica hybrid monolith were depicted by ATR-FTIR analysis. Similar spectral peaks were observed for all samples, revealing no significant contribution of difference in the weight and type of PEG content on the type of functional groups. Figure 1 exhibits FTIR spectra for monoliths with different ratios of the amount and molecular weight for PEG used, with respect to Figure 1(a) for hybrid monolith with PEG 10,000 $M_{n}$ while Figure 1(b) for hybrid monolith with PEG 20,000 $M_{n}$, both in different amounts of $0.1 \mathrm{~g}, 0.2 \mathrm{~g}$, and $0.3 \mathrm{~g}$. All samples of monoliths showed strong peaks at around $790-800 \mathrm{~cm}^{-1}$ ascribed to the Si-O-Si symmetric stretching vibrations, similar to the previously described silica nanostructure gel and microstructure capillary prepared by sol-gel synthesis $[18,24]$.

The vibrational bands around $945-955 \mathrm{~cm}^{-1}$ showed the presence of Si-OH groups from the silanol functionality of the hybrid monolith, where this is the band that strongly represented the mesoporous structure of silica monolith. This finding is also similar to those reported previously for the mesoporous silica with with alkoxysilane groups [25]. This silanol group is significant to the monolith formation in order to provide a hydroxyl functional group which is important in the subsequent covalent attachment of enzyme by means of a crosslinker [19]. Intense peaks were observed around $1050-1080 \mathrm{~cm}^{-1}$ showing the Si-O-Si asymmetric stretching vibrations. Previously, Nocuń et al. [26] suggested that the hybrid monolith will transmit a strong absorption band for Si-O-Si as a characteristic after the modification of pure silica gel [26]. List of functional groups in polymer-silica hybrid monolith tabulated in Table 1.

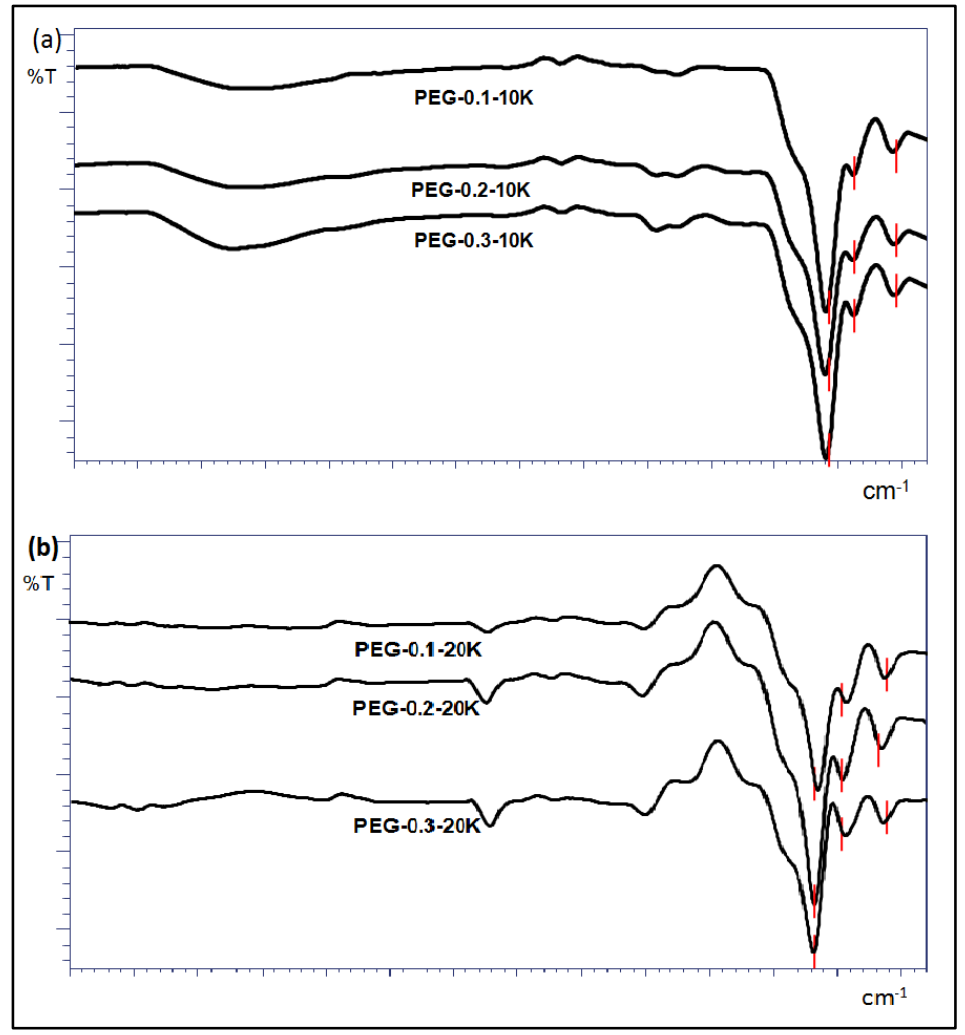

Figure 1. FTIR spectrum of polymer-silica hybrid monolith (a) PEG $\left(\mathrm{M}_{\mathrm{n}}=10,000\right)$ with different weight used, (b) PEG $\left(\mathrm{M}_{\mathrm{n}}=20,000\right)$ with different weight used 
Table 1. List of functional groups in polymer-silica hybrid monolith

\begin{tabular}{llcccccc}
\hline \multirow{2}{*}{$\begin{array}{l}\text { Functional } \\
\text { Group }\end{array}$} & Type of Vibration & \multicolumn{5}{c}{ Frequency $\left(\mathbf{c m}^{-1}\right)$} \\
\cline { 3 - 7 } & & \multicolumn{3}{c}{ PEG $\left(\mathbf{M}_{\mathbf{n}}=\mathbf{1 0 , 0 0 0}\right)$} & \multicolumn{2}{c}{ PEG $\left(\mathbf{M}_{\mathbf{n}}=\mathbf{2 0 , 0 0 0}\right)$} \\
\cline { 3 - 7 } & & $\mathbf{0 . 1 g}$ & $\mathbf{0 . 2 g}$ & $\mathbf{0 . 3 g}$ & $\mathbf{0 . 1 g}$ & $\mathbf{0 . 2 g}$ & $\mathbf{0 . 3 g}$ \\
\hline Si-O-Si & Symmetric stretching vibrations & 790.81 & 790.81 & 792.74 & 796.60 & 796.6 & 798.53 \\
$\mathrm{Si}-\mathrm{OH}$ & Bond vibration & 947.81 & 952.84 & 952.84 & 941.26 & 945.12 & 945.12 \\
$\mathrm{Si}-\mathrm{O}-\mathrm{Si}$ & Asymmetric stretching vibrations & 1053.13 & 1060.85 & 1060.85 & 1049.28 & 1053.13 & 1068.56 \\
\hline
\end{tabular}

\section{Effect of variation in the PEG porogen concentrations}

The effect of porogen concentrations onto monolithic textural properties was investigated with varying amounts of PEG $\left(\mathrm{M}_{\mathrm{n}}=10,000\right)$ from $0.1 \mathrm{~g}$ to $0.3 \mathrm{~g}$. The samples were denoted as PEG-0.1 $10 \mathrm{~K}$, PEG-0.2 $10 \mathrm{~K}$, and PEG-0.3 10 $\mathrm{K}$, respectively. Figures 2(a) and (b) show that a mesoporous structure can be seen for the hybrid monolith with 0.1 $\mathrm{g}$ and $0.2 \mathrm{~g}$ of PEG added while for Figure 2(c), the increasing amount of porogen to $0.3 \mathrm{~g}$ PEG will make the hybrid monolith to become a homogeneous and porous monolithic structure. The addition of different amounts of PEG acted as an organic porogen will provide higher porosity to the monolithic network, where the then organic modifier will make the structure less compact [26]. However, our findings also show that this structure will eventually become agglomerated when the concentration of porogen increased.
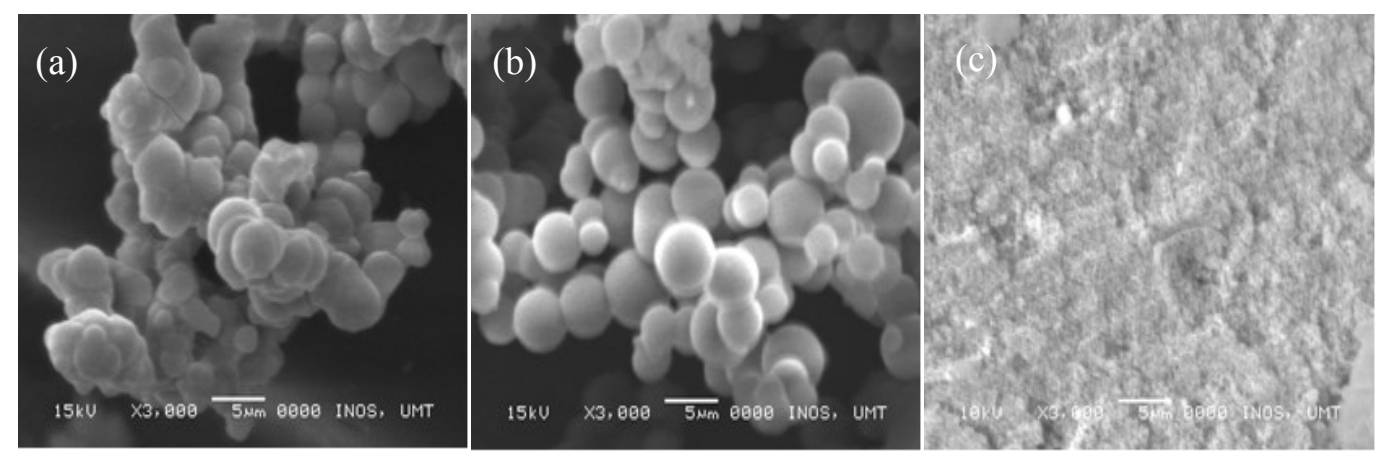

Figure 2. SEM images of polymer-silica hybrid monolith made with different amount of PEG 10,000 $M_{n}$ used: (a) PEG-0.1, (b) PEG-0.2, (c) PEG-0.3, at 3000x magnification

Figure 3 shows the isothermal linear plots for all the monolith samples made from PEG $10,000 \mathrm{M}_{\mathrm{n}}$ for $0.1 \mathrm{~g}$ to $0.3 \mathrm{~g}$. The nitrogen gas adsorption/desorption isotherm study from Brunauer-Emmett-Teller (BET) method of the hybrid monoliths presented the applicability of $\mathrm{H}_{3}$-type hysteresis loop with well-defined Type IV(a) isotherm for all the synthesized samples, which confirmed the presence of mesopore structures in the monolith. In the case of Type IV(a) isotherm, the capillary condensation might occur when the pore width exceeded to a certain critical width, depending on the adsorption system and temperature [27]. These findings were supported by the measurement of BET surface area as shown in Table 2. The specific surface determined by BET method was related to the total surface area (reactive surface) as all porous structures adsorb the small gas molecules. The results showed that increased amount of porogen used made the monolith surface area became smaller, for instance, the use of $0.1 \mathrm{~g}$ PEG 10,000 Mn showed a significant amount of $494.121 \mathrm{~m}^{2} / \mathrm{g}$ surface area, compared to when using $0.2 \mathrm{~g} \mathrm{(457.586}$ $\left.\mathrm{m}^{2} / \mathrm{g}\right)$ and $0.3 \mathrm{~g}\left(431.102 \mathrm{~m}^{2} / \mathrm{g}\right)$ of PEG. This might be due to the reactive surface that decreased as the surface area became smaller. Additionally, the results measured for the pore volume and size that were obtained by the BarrettJoyner-Halenda (BJH) method showed that as the amount of PEG used increased, the pore size for each monolith also increased where the $0.1 \mathrm{~g}$ PEG of $10,000 \mathrm{M}_{\mathrm{n}}$ resulted with $2.797 \mathrm{~nm}, 0.2 \mathrm{~g}$ PEG of $10,000 \mathrm{M}_{\mathrm{n}}$ resulted with $3.49 \mathrm{~nm}$, and $0.3 \mathrm{~g}$ PEG of $10,000 \mathrm{M}_{\mathrm{n}}$ resulted in $9.348 \mathrm{~nm}$ in pore diameters. On the other hand, the pore volume of each monolith also became bigger, as described in Table 2 . 


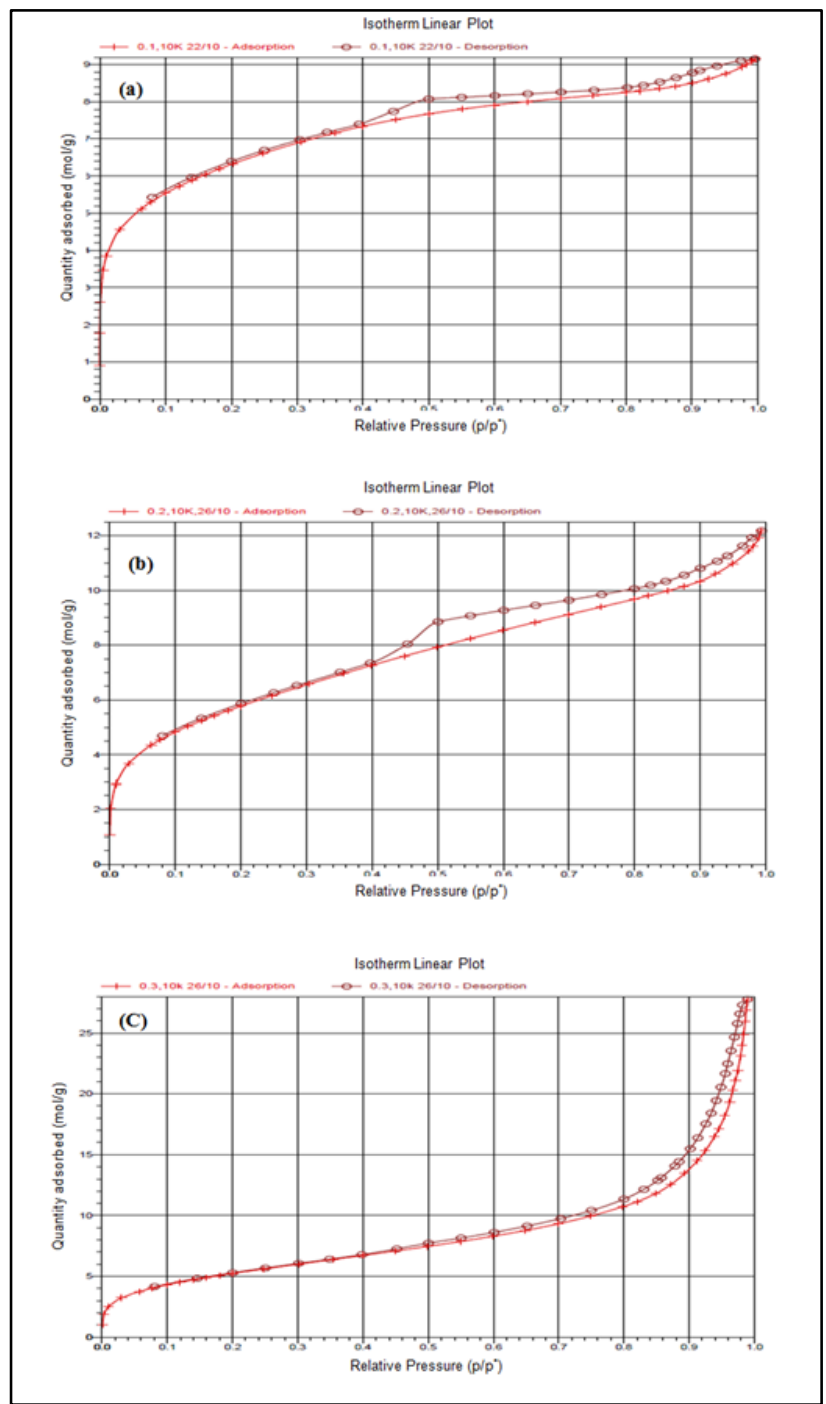

Figure 3. $\mathrm{N}_{2}$ adsorption-desorption isotherm of polymer-silica hybrid monoliths with PEG 10,000 $\mathrm{M}_{\mathrm{n}}$ for (a) PEG-0.1, (b) PEG-0.2, (c) PEG-0.3

Table 2. Surface area, pore size and pore volume measurement for PEG of $10,000 \mathrm{M}_{\mathrm{n}}$ using BET and BJH methods

\begin{tabular}{|c|c|c|c|}
\hline \multirow{2}{*}{$\begin{array}{l}\text { Weight } \\
\text { (g) }\end{array}$} & \multirow{2}{*}{$\begin{array}{l}\text { Brunauer- Emmett-Teller } \\
\text { (BET) Surface Area }\left(\mathrm{m}^{2} / \mathrm{g}\right)\end{array}$} & \multicolumn{2}{|c|}{ Barrett-Joyner-Halenda (BJH) } \\
\hline & & $\begin{array}{c}\text { Pore Volume } \\
\left(\mathrm{cm}^{3} / \mathrm{g}\right)\end{array}$ & $\begin{array}{l}\text { Pore size } \\
\text { (nm) }\end{array}$ \\
\hline 0.1 & 494.121 & 0.265 & 2.797 \\
\hline 0.2 & 457.586 & 0.467 & 3.549 \\
\hline 0.3 & 431.102 & 0.949 & 9.348 \\
\hline
\end{tabular}

\section{Effect of variations in porogen type}

The effect of different porogen types onto monolithic textural properties was also assessed by using different molecular weights for $0.1 \mathrm{~g}$ of poly(ethylene-glycol)(PEG) with $\mathrm{M}_{\mathrm{n}}$ of 10,000 and 20,000. The samples were 
denoted as PEG-0.1-10K and PEG-0.1-20K, respectively. Figure 4 shows the SEM images with different magnifications, verifying that very porous structure and interconnecting network are visible for both PEG-0.1-10K and PEG-0.1-20K synthesized in TEOS, that yielded to a continuous skeleton structure monolith. This result is consistent with the previous study that used 3-mercaptopropyltrimethoxysilane (MPTMS) as a porogen precursor for silica monolith synthesis in the presence of TEOS where the addition of organic monomer helped in introducing the organic moiety to the silica backbone during the preparation of monolith [15, 20, 28]. In Figure 4, the higher magnification images for 5000x magnification (inset) displayed that the skeleton of the monolithic network joined together, building up interconnected spheres in globules form (Figure 4(a)) and also in very homogenous spheres form (Figure 4(b)). The SEM images show that both types of PEG resulted in different characteristics of mesoporous structures. Therefore, the surface area and porosity of each monolith were analyzed using the BET and $\mathrm{BJH}$ method, respectively in order to determine the porosity and surface area of the monoliths.
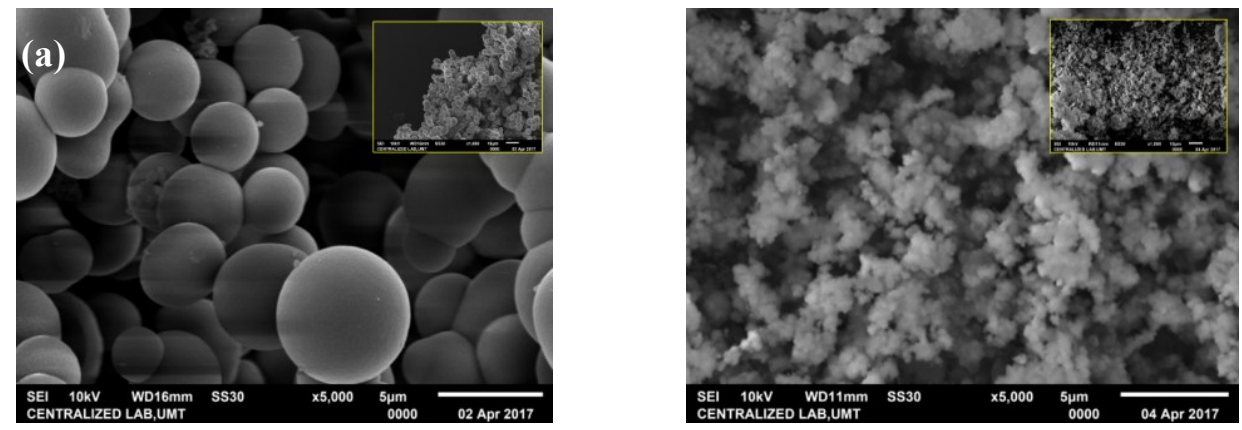

Figure 4. SEM images of polymer silica-hybrid monolith with different molecular weight (a) PEG-0.1-10K for 5000x magnification (inset: 1000x), (b) PEG-0.1-20K for $5000 \mathrm{x}$ magnification (inset: 1000x)

The nitrogen gas adsorption-desorption isotherm of the hybrid monoliths with 0.1g PEG with $10,000 \mathrm{M}_{\mathrm{n}}$ (PEG-0.1-

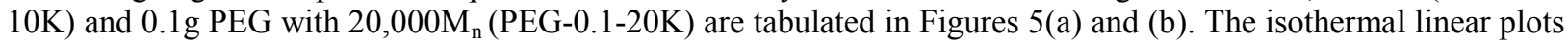
for both samples revealed a $\mathrm{H}_{3}$-type hysteresis loop with well-defined type IV isotherms. The surface area calculated using the BET method gave a value of $494.121 \mathrm{~m}^{2} / \mathrm{g}$ for hybrid monolith PEG-0.1-10K used and 468.830 $\mathrm{m}^{2} / \mathrm{g}$ for hybrid monolith PEG-0.1-20K. This shows that the lower molecular weight of porogen is more desirable for the synthesis of the higher surface value of support. The volume of nitrogen gas adsorbed for the isotherms increased sharply, starting from 0.5 of relative pressure $(\mathrm{p}=\mathrm{p} 0)$ (Figure $5(\mathrm{a})$ ). This behavior might signify the capillary condensation of nitrogen gas within the continuous mesoporous structures [29, 30]. Additionally, based on the BJH report for the porosity study (report not included), for the sample with $0.1 \mathrm{~g}$ of PEG with 10,000 molecular weight (PEG-0.1-10K), the pore volume and size appeared to be $0.265 \mathrm{~cm}^{3} / \mathrm{g}$ and $2.797 \mathrm{~nm}$, respectively while the same amount of PEG with 20,000 molecular weight ((PEG-0.1-20K) only gave a slightly different pore value of $0.264 \mathrm{~cm}^{3} / \mathrm{g}$ pore volume and $2.762 \mathrm{~nm}$ pore size. Therefore, while the surface area can be different for both types of the monolith, it can be agreed that there is not much different in the monolith porosity of using different molecular weights of PEG as porogen as compared to the different amounts of PEG used in each hybrid monolith sample preparation. 


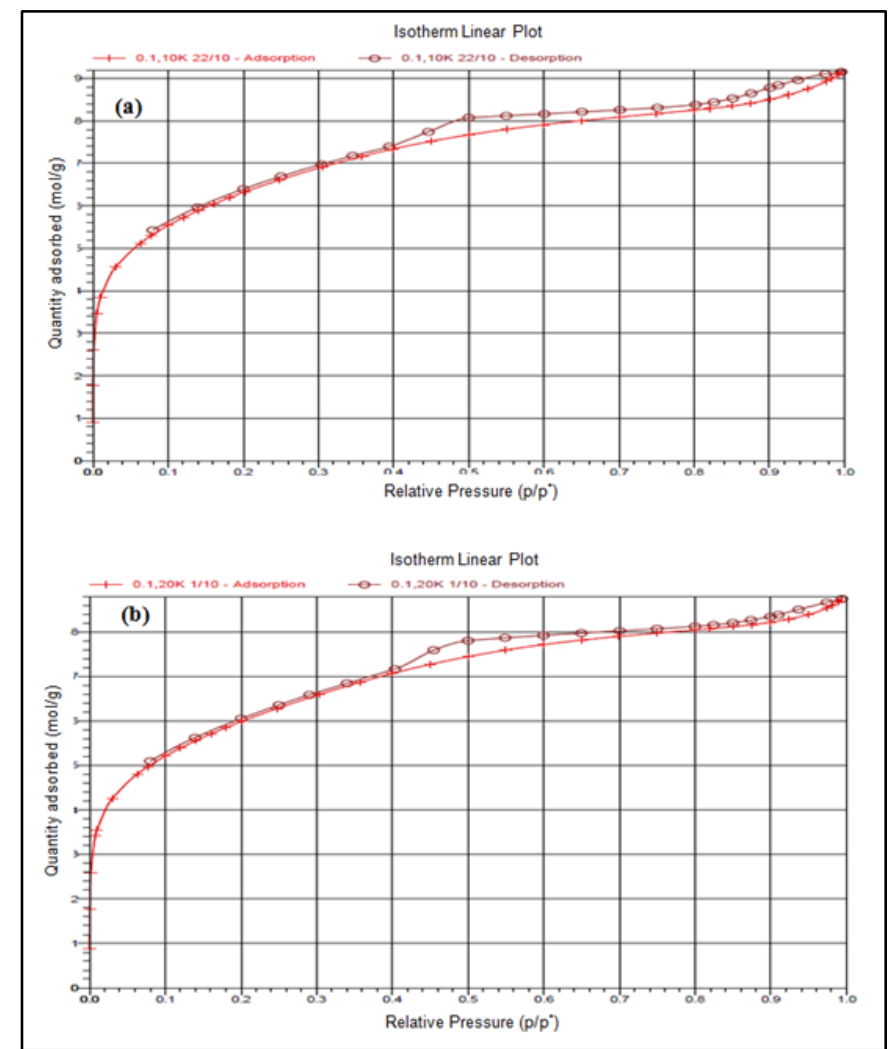

Figure 5. The Nitrogen gas adsorption-desorption isotherm of the hybrid monoliths with (a) PEG-0.1-10K and (b) PEG-0.1-20K

\section{Conclusion}

The fabrications of the hybrid monolith as a precursor for manufacturing enzyme support were accomplished by employing in-situ conventional sol gel method as described. All the synthesized monoliths were found to be having a porous structure. It was proven that diversified mesoporous structures can be tuned using different amounts and types of the porogen. Results showed that the most optimum condition for hybrid monolith synthesis was using PEG-0.1-10K. It can be concluded that the synthesized polymer-silica hybrid monolith permits a great surface area with a desirable functional group of silanol for further enzyme immobilization support. In future, this kind of support will be such a good platform for lipid modification and rapid lipid analysis, especially in a small scale analytical reaction.

\section{Acknowledgements}

The authors would like to thank the Malaysian Ministry of Higher Education (MOHE) for FRGS Research grant given to Dr. Sabiqah T. Anuar (59327) and MOHE MyBrain15 for providing graduate student funding (Noor Hidayah Idrohani). The authors also acknowledge the analytical and technical supports from Dr. Alyza A. Azmi for technical advice and Dr. Mohd Hasmizam Bin Razali from the School of Fundamental Sciences, UMT for providing technical help on the BET and BJH analyses.

\section{References}

1. Vázquez, M. and Paull, B. (2010). Review on recent and advanced applications of monoliths and related porous polymer gels in micro-fluidic devices. Analytica Chimica Acta, 668(2): 100 - 113.

2. Nema, T., Chan, E. C. Y. and Ho, P. C. (2014). Applications of monolithic materials for sample preparation. Journal of Pharmaceutical and Biomedical Analysis, 87: 130 - 141. 
3. Bakry, R., Huck, C. W. and Bonn, G. K. (2009). Recent applications of organic monoliths in capillary liquid chromatographic separation of biomolecules. Journal of Chromatographic Science, 47(6): 418 - 431.

4. Gaweł, B., Gaweł, K. and Øye, G. (2010). Sol-gel synthesis of non-silica monolithic materials. Materials, 3(4): $2815-2833$.

5. Nic, M., Jirat, J., and Kosata, B. (2012). IUPAC gold book. http://goldbook.iupac.org/MT07559.html. [Access online 02 April 2016].

6. Svec, F. (2002). Advances in biochemical engineering/biotechnology: Modern advances in chromatography. Springer-Verlag Berlin Heidelberg, New York. 76: pp. $1-47$.

7. Rieux, L., Niederländer, H., Verpoorte, E. and Bischoff, R. (2005). Silica monolithic columns: Synthesis, characterisation and applications to the analysis of biological molecules. Journal of Separation Science, 28(14): $1628-1641$.

8. Nordborg, A. and Hilder, E. F. (2009). Recent advances in polymer monoliths for ion-exchange chromatography. Analytical and Bioanalytical Chemistry, 394(1): 71 - 84.

9. Xu, Y., Cao, Q., Svec, F. and Fréchet, J. M. J. (2010). Porous polymer monolithic column with surface-bound gold nanoparticles for the capture and separation of cysteine-containing peptides. Analytical Chemistry, 82(8): $3352-3358$.

10. Lv, Y.-Q., Fu, D.-Y., Tan, T.-W. and Wang, M.-Y. (2010). One-step purification of YLLIP2 isoforms from Candida sp. 99-125 by polyethyleneimine modified poly(glycidyl methacrylate-co-ethylene glycol dimethacrylate) monolith. Journal of Molecular Catalysis B: Enzymatic, 62(2): 149 - 154.

11. Chen, M. L., Wei, S. S., Yuan, B. F. and Feng, Y. Q. (2012). Preparation of methacrylate-based monolith for capillary hydrophilic interaction chromatography and its application in determination of nucleosides in urine. $J$ ournal of Chromatography A, 1228: $183-192$.

12. Liu, W., Qi, J., Yan, L., Jia, Q. and Yu, C. (2011). Application of poly(butyl methacrylate-co-ethylene glycol dimethacrylate) monolith microextraction coupled with high performance liquid chromatography to the determination of polycyclic aromatic hydrocarbons in smoked meat products. Journal of Chromatography B, 879 (28): $3012-3016$.

13. Li, Y., Qi, L. and Ma, H. (2013). Preparation of porous polymer monolithic column using functionalized graphene oxide as a functional crosslinker for high performance liquid chromatography separation of small molecules. The Analyst, 138(18): 5470 - 5478.

14. Nandi, M. and Uyama, H. (2014). Porous acrylate monolith supported Pd nanoparticles: Highly active and reusable catalyst for Suzuki-Miyaura reaction in water. RSC Advances, 4(40): 20847 - 20855.

15. Ou, J., Lin, H., Zhang, Z., Huang, G., Dong, J. and Zou, H. (2013). Recent advances in preparation and application of hybrid organic-silica monolithic capillary columns. Electrophoresis, 34(1): 126 - 140.

16. Yuan, H., Zhang, L. and Zhang, Y. (2012). Comprehensive sampling and sample preparation: Analytical techniques for scientists. Academic Press, Elsevier Inc, Amsterdam. 2: pp. 345 - 358.

17. Xu, L. and Lee, H. K. (2008). Preparation, characterization and analytical application of a hybrid organicinorganic silica-based monolith. Journal of Chromatography A, 1195 (1-2): 78 - 84.

18. Anuar, S. T., Zhao, Y-Y., Mugo, S. M. and Curtis, J. M. (2013). The development of a capillary microreactor for transesterification reactions using lipase immobilized onto a silica monolith. Journal of Molecular Catalysis B: Enzymatic, 92: 62 - 70 .

19. Anuar, S. T., Mugo, S. M. and Curtis, J. M. (2015). A flow-through enzymatic microreactor for the rapid conversion of triacylglycerols into fatty acid ethyl ester and fatty acid methyl ester derivatives for GC analysis. Analytical Methods, 7(14): 5898 - 5906.

20. Wu, M., Wu, R., Zhang, Z. and Zou, H. (2011). Preparation and application of organic-silica hybrid monolithic capillary columns. Electrophoresis, 32(1): $105-115$.

21. Wang, J., Wu, F., Xia, R., Zhao, Q., Lin, X. and Xie, Z. (2016). Rapid fabrication of ionic liquid-functionalized monolithic column via in-situ urea-formaldehyde polycondensation for pressurized capillary electrochromatography. Journal of Chromatography A, 1449: 100 - 108.

22. Xie, C., Ye, M., Jiang, X., Jin, W. and Zou, H. (2006). Octadecylated silica monolith capillary column with integrated nanoelectrospray ionization emitter for highly efficient proteome analysis. Molecular and Cellular Proteomics, $454-461$.

23. Hayes, J. and Malik, A. (2000). Sol-gel monolithic columns with reversed electroosmotic flow for capillary electrochromatography. Analytical Chemistry, 72(17): 4090 - 4099. 
24. Battisha, I. K., El Beyally, A., Abd El Mongy, S. and Nahrawi, A. M. (2007). Development of the FTIR properties of nano-structure silica gel doped with different rare earth elements, prepared by sol-gel route. Journal of Sol-Gel Science and Technology, 41 (2): 129 - 137.

25. Andrade, G. F., Soares, D. C. F., Almeida, R. K. D. S. and Sousa, E. M. B. (2012). Mesoporous silica SBA-16 functionalized with alkoxysilane groups: preparation, characterization, and release profile study. Journal of Nanomaterials, 2012: 1 - 10.

26. Nocuń, M., Siwulski, S., Leja, E. and Jedliński, J. (2005). Structural studies of TEOS-tetraethoxytitanate based hybrids. Optical Materials, 27(9): 1523 - 1528.

27. Thommes, M., Kaneko, K., Neimark, A. V., Olivier, J. P., Rodriguez-reinoso, F., Rouquerol, J. and Sing, K. S. W. (2015). Physisorption of gases, with special reference to the evaluation of surface area and pore size distribution (IUPAC Technical Report), Pure and Applied Chemistry, 87(9-10): 1051 - 1069.

28. Zheng, M. M., Ruan, G. D. and Feng, Y. Q. (2009). Hybrid organic-inorganic silica monolith with hydrophobic /strong cation-exchange functional groups as a sorbent for micro-solid phase extraction. Journal of Chromatography A, 1216(45): 7739 - 7746.

29. Thejaswini, T. V. L., Prabhakaran, D. and Maheswari, M. A. (2017). Structurally engineered $\mathrm{TiO}_{2}-\mathrm{SiO}_{2}$ monolithic designs for the enhanced photocatalytic degradation of organic textile dye pollutants. Functional Ma terials Letters, 10(2): $2-5$.

30. Ahmad, A., Razali, M.H., Kassim, K. and Mat Amin, K.A. (2017). Synthesis of multiwalled carbon nanotubes supported on M/MCM-41 ( $\mathrm{M}=\mathrm{Ni}$, Co and $\mathrm{Fe})$ mesoporous catalyst by chemical vapour deposition method. Journal of Porous Materials, 1-9. 